\title{
ACCOUNTING OPPORTUNITIES FOR DEPRECIATION OF A COW HERD
}

\author{
E. Georgieva*, N. Penev
}

Faculty of Economy and Social Sciences, Plovdiv University Paisii Hilendarski, Plovdiv, Bulgaria

\begin{abstract}
Accounting in the agrarian sector is regulated by International Accounting Standard 41: Agriculture and its Bulgarian equivalent National Accounting Standard 41: Agriculture. The possible approaches in estimating the non-current biological assets are two: A) fair value, reduced by sales costs; B) historical cost, determined by the asset acquisition costs.

The adoption of the first approach by the agricultural enterprises requires the use if evaluations, established at a market base. Non-current biological assets are excluded from the range of amortization assets. The accounting based on historical cost includes accrual of depreciation of noncurrent biological assets.

The purpose of the study is to analyze both possible approaches for evaluation of non-current biological assets regulated by the accounting legislation. On this basis we shall determine the influence of depreciation on the financial results of the agricultural enterprise, implemented by the management of a main dairy herd.
\end{abstract}

Key words: non-current biological assets; amortization; historical cost

\section{INTRODUCTION}

The sustainable development of agriculture as a branch of the economy presupposes the building of efficient accounting system relevant to the accounting and tax legislation. The separation of biological assets as carriers and the exclusion of plants from the range of IAS 41: Agriculture and their inclusion into IAS 16: Property, Plant and Equipment presented the opportunity to apply historical cost as a model for evaluation of biological assets.

The purpose of this study is to reveal the possibilities for valuation of animal carriers at a historical cost and the related depreciations through an analysis of the accounting and tax laws.

The object of the study is a main dairy herd, raised for dairy production. The opportunity to depreciate productive animal reflects on the value of production, acquired during their raising: yoghurt and weight gain. The realized financial result of the farms is directly dependent on the size of production costs, and

\footnotetext{
*orrespondence to: E. Georgieva, Plovdiv University Paisii Hilendarski, Plovdiv, Bulgaria, Faculty of Economy and Social Sciences, elena_ketk@abv.bg
}

in particular the accounting and tax depreciations.

\section{METHODS}

In order to achieve this aim we have first viewed the possibilities to evaluate the biological assets carriers, and second, we have analyzed the opportunities for an accrual-based depreciation of animals in a main herd and the effects on the financial results on the farm; third, we have analyzed the tax law; and fourth we have drawn conclusions and recommendations for tackling the problem.

\section{RESULTS}

Raising dairy cattle is a structurally defining production in agriculture in Bulgaria. Milk production has been growing in the recent years with a retained average annual indicator of livestock farms (Table 1) according to data from the Ministry of Agriculture and Foods, Department of Agrostatistics. For the past five years the sector has marked a constant increase of the amount of production (cow milk), which is a sign for the growing impact of the sector on economic development, as well as of the country, and the separate regions. 
GEORGIEVA E., et al.

Table 1. Development of the dairy cattle sector in the Republic of Bulgaria for the period 2009-2013

\begin{tabular}{|l|c|c|c|c|c|}
\hline & $\mathbf{2 0 0 9}$ & $\mathbf{2 0 1 0}$ & $\mathbf{2 0 1 1}$ & $\mathbf{2 0 1 2}$ & $\mathbf{2 0 1 3}$ \\
\hline $\begin{array}{l}\text { Cows-Milk in Heads } \\
\text { Average farm performance }\end{array}$ & 5 & 4 & 4 & 4 & 5 \\
\hline $\begin{array}{l}\text { Gross production of cow's milk } \\
\text { in thousands of BGN }\end{array}$ & 3868,6 & 4017,2 & 4443,6 & 6452 & 10004 \\
\hline
\end{tabular}

Source: MAF, Agrostatistics Department, Farm Accountancy Data System

Accounting in agriculture is regulated by IAS 41 Agriculture and its Bulgarian equivalent NAS 16 Agriculture. On 01.06.2016 the regulations of IAS 41 Agriculture specifically required agricultural enterprises to announce their biological assets as carriers and users (IAS 41, paragraph 43-44) and if possible, as mature and immature (IAS 41, paragraph 45). The biological assets are defined as living plants or animals, regardless of their species, origin, purpose and expected economic profit (Pancheva 2013). Carriers are such assets which allow the yield of agricultural production for a period longer than one year, and according to their economic characteristics are defined as non-current. According to Regulation (EO) 2113/2015 OB L306, 24.11.2015 (EC 2015) plant carriers are separated from the other biological assets and are included into the long-term material assets within the range of IAS 16 Property, plant and equipment. During the organization of accounting it is necessary to apply the rules and practices which are established for the other long-term material assets, used in farm activity (facility fund, equipment, etc.).

To organize the accountability of biological assets efficiently, it is important to review the main concepts in standard IAS 41 Agriculture, as well as the mechanisms for their application (Atanasov 2012), where one of the aspects is to define the group of animal carriers. According to data from the Ministry of Agriculture and Foods, Department of Agrostatistics, the most frequently raised species are cattle, including dairy cows, buffaloes, pigs, sheep, and goats. The common economic characteristic of the indicated species is the length of their rearing as productive animals: from five years for sheep up to 10 years for dairy cattle. This fact, combined with their raising purpose, and agricultural production yield is the reason to group animals into main herds as carriers. Poultry of the largest economic importance are hens, turkeys, ducks and geese, but the technology of their rearing defines them as animal carriers. The accounting law regulates the model of evaluation of biological assets and the obtained production: fair value, reduced by sale costs reflects best the specifics of biological assets (Lefter, V. Roman,
A.2007; Bohusova, H, Svoboda.P.2017). The evaluation model is related to the formation both of the financial result of agricultural enterprises, as well as with its tax justification (Gerganov, G. 2013).

The inclusion of plant carriers within the range of IAS 16: Property, plant and equipment allowed the application of historical cost as an evaluation model of biological assets (IAS 16, paragraph 15). In the range of IAS 41 Agriculture this is possible only in cases when the fair value cannot be reliably assessed (IAS 41, paragraph 30). It is important to note that calculating assets on a fair value is limited in accounting legislation and has been narrowed for the past decade (Christensen, Hans B., andValeri V. Nikolaev, 2013). Application of the principle of the historical cost is related to accrual of depreciation, through which the accounting value of the amortization assets is corrected. Their influence on the financial state of agricultural enterprises has two aspects:

1. As an element of the cost for the production according to the size of the enterprise it reflects on the size of the realized accounting profit;

2. As an element of the financial result for tax purposes it influences the size of the due income tax.

The agricultural enterprises account for the acquired production of biological assets with an initial recognition of fair value, reduced by sales costs (IAS 41, paragraph 13). The process of calculation of the cost in agriculture includes systematization and grouping of production costs: direct material, direct labour and common production costs (Rozentale, S., Ore, M. 2013). This process is an inseparable part of the organization of accounting of agricultural activity and is of key importance for the efficient management of agricultural enterprises.

The amortization costs need to be viewed as an element of both the accounting policy of the enterprise (Georgieva, V. 2014), and the fiscal policy of the state. The animal carriers, including dairy cows are within the range of IAS 41 Agriculture and are assessed according to fair value, reduced by the sales costs and do not belong to the group of amortization assets. 
On the date of each balance the available animals must be presented on a fair value, reduced by sales costs (IAS 41, paragraph 15), and the any differences must be included in the financial result for the period, during which they have occurred (IAS 41, paragraph 26). Therefore, the changes in the evaluation of main animals are an element of the accounting financial result, but they do not influence the cost of the yielded products (milk and weight gain of calves up to 6 months).

Amortization of long-term material and immaterial assets is regulated by the tax legislation through the regulations of the Law of corporate income taxation, Chapter 10 - Tax amortization assets. Animal carriers are not an object of tax amortization, because they do not meet the requirements regulated by the law (Law of corporate income taxation, article 50): to be subdued to amortization, according to the applicable accounting standards and to have an acquisition value of over 700 BGN. According to the regulations of IAS 41 Agriculture, the income and expenses, which have occurred during the evaluation of biological assets, are included in the financial result for the period of their occurrence (IAS 41, paragraph 28). For tax purposes the assets are accepted for the year of derecognition of the assets from the accounting registers (Law of corporate income taxing, article 36), and as a result of which temporary tax differences for the period of exploitation of the biological asset are formed.

The agricultural enterprises, which evaluate animal carriers at fair value reduced by sales costs, face the problem regarding the following aspects of their accountability:

1. The value of the reared main animals does not reflect on the cost of the yielded production, because they do not have the character of production costs (IAS 2, paragraph 10-15);

2. The accounted income and expenses of the reevaluation of animal carriers are not recognized for tax purposes, because they do not participate in the recalculation of the tax base for income taxation of the activity;

3. The carrying value of the animal carriers is the sum, with which they are represented in the financial report (IAS 41, paragraph 6) and which is formed by their carrying amount corrected with the accounting reevaluations. This norm separates them from the other long-term material assets, owned by the agricultural enterprises. Carrying value is the amount with which the asset is recognized in the financial report, after deduction of accrued amortizations and depreciations (IAS 16, par. 6).
Agricultural enterprises are given the opportunity to account for their reared animal carriers at historical cost if it is not possible to determine reliably their fair value (IAS 41, par. 30). The application of the norm equalizes this group of long-term biological assets to plant carriers: it includes them into the range of IAS 16: Property, plants and equipment. Animal carriers are included in the group of amortization assets and meet the requirements of the Law of corporate income taxation, in the part where amortization for tax purposes is regulated.

The application of the historical cost during evaluation and estimation of animal carriers reflects on the accounting system of agricultural enterprises in the following aspects:

1. The value of the reared main animals influences the cost of the yield of agricultural production through the size of accrued accounting amortization;

2. The influence of this group of biological assets on the due income tax is of the size of the accrued tax amortizations;

3. The carrying value of animal carriers is the amount with which the asset is recognized in the financial report after deducing the accrued amortization and depreciation (IAS 16, par. 6).

According to the regulations of the Law of corporate income taxation it is necessary to amortise animal carriers for tax purposes with an amortization norm of $15 \%$ or for a period of 6 years and 8 months (Law of corporate income taxation, article 55). Referred to the technological term for rearing main dairy herd of 10 years, this period is too short.

The agricultural enterprise which applies historical cost as a basis for evaluating the long-term biological assets needs to decide what norm of accounting amortization of animals in main herds to choose according to the term of their usefulness (IAS 16, paragraph 57). In dairy cattle raising the annual amortization norm is determined as a ratio between the amortization amount of the asset, taken as $100 \%$ to the term of raising a productive animal in years 10 years $(100 / 10=10 \%)$. The size of the accrued amortization is a product of the amortization amount and the amortization norm. After exhausting the technological possibilities of the dairy cow, her residual value is too low and does not have a significant impact on the size of the amortization amount. On estimating the tax financial result temporary tax differences of $5 \%$ of the amortization amount are formed. 
In Bulgaria the requirement for writing the financial report of the enterprise for tax purposes is not regulated, but rather an annual tax form is prepared.

As a conclusion for the above mentioned arguments the following statement is proposed: a country through the regulations of the Law of corporate income taxation regulates higher amortization norms for animal carriers, evaluated at a historical cost. They are unacceptable for the agricultural enterprises because they do not correspond to the term of usefulness of the main animals and apply accounting norms relevant to the technological characteristics of the production process. As a result, the agricultural enterprises reach an effect in two aspects:

1. The size of the accounting amortizations is added to the cost of the yielded production from the main herd with an annual amortization norm of $10 \%$, which referred to the tax amortization norm is a reduction of $5 \%$ of the amortization amount.

2. The tax amortization norms are applied at calculation of the financial result during taxation, which additionally reduces the size of the due tax. As a result, the state fiscal income is reduced.

The object of the present study is a dairy herd raised by "Theodora Petrova" EOOD, a registered agricultural producer. The number of dairy cows is 55 and they are reared in Gorna Mahala village, Plovdiv region. The value of acquiring the cows on registration as main herd animals varies from 1400 to 1600 BGN depending on the period of acquisition and the biological characteristics of the animals.
The average weight of the dairy cow is $550 \mathrm{~kg}$, and the residual value is determined by the market of $1 \mathrm{BGN} / \mathrm{kg}$, regarded by the enterprise as insignificant.

The impact of the evaluation of dairy cows on the financial result of the enterprise is determined by the adopted evaluation mechanism. The study analyzes three possible options: 1. Evaluation at fair value, reduced by the sales costs; 2. Evaluation at historical cost with adoption of accounting norms, relevant to the technological terms for raising dairy cows; 3. Evaluation at a historical cost with adoption of tax amortization norms.

Two groups of factors affect the formation of fair value of dairy cows: 1 . Influence of the biological transformation; 2. Influence of the market mechanisms.

The long-term biological assets are characterized with a relatively constant technological efficiency during the whole period of exploitation. Therefore, the impact of the biological transformation in regard to the evaluation of the dairy cows is negative: aging, diseases, reduced productivity. Such biological changes must be registered for each animal depending on their physical state, which is complicated and extensive. As a result, the main animals (dairy cows) are deprecated and reduce their carrying value.

The market mechanisms influence the increase and the decrease of values. The lack of regulated markets in respect to dairy cows hinders the accurate determination of the impact of market mechanisms on the fair value. The size of the admitted re-evaluation of the main animals is the result of the interaction between the two factors and is presented in Table 2.

Table 2. Influence of biological transformation and market mechanisms in subsequent evaluation of dairy cow

\begin{tabular}{|l|c|c|c|c|c|}
\hline \multicolumn{1}{|c|}{ Options } & $\begin{array}{c}\text { Reporting } \\
\text { value of } \\
\text { dairy cow }\end{array}$ & $\begin{array}{c}\text { Impairment due } \\
\text { to biological } \\
\text { transformation }\end{array}$ & $\begin{array}{c}\text { Influence of } \\
\text { market } \\
\text { mechanisms }\end{array}$ & $\begin{array}{c}\text { Reported } \\
\text { Net fair } \\
\text { value }\end{array}$ & $\begin{array}{c}\text { difference in } \\
\text { subsequent } \\
\text { evaluation }\end{array}$ \\
\hline $\begin{array}{l}\text { Formation of a fair price } \\
\text { in case of a decrease in } \\
\text { value due to biological } \\
\text { processes }\end{array}$ & 1500 & -200 & -300 & 1000 & -200 \\
\hline $\begin{array}{l}\text { Forming a fair price in } \\
\text { case of a decrease in value } \\
\text { as a result of biological } \\
\text { processes and a decrease } \\
\text { in market prices }\end{array}$ & 1500 & -200 & -300 & 100 \\
\hline $\begin{array}{l}\text { Forming a fair price in } \\
\text { case of a decrease in value } \\
\text { as a result of biological } \\
\text { processes and an increase } \\
\text { in market prices }\end{array}$ & 1500 & -200 & 300 & 1600 & 100 \\
\hline
\end{tabular}


Regardless of the size of the estimated reevaluation of the dairy cows, it does not affect the cost of the products and the financial result for tax purposes.

During the evaluation of the dairy cows at historical cost an accounting and tax amortization plan is prepared in which the amortization norms of the asset and the term of its amortization are set out. The influence of the accounting amortization at an annual norm of $10 \%$ in respect to the technological term of raising dairy cows is presented in Table $\mathbf{3}$.

Table 3. Amount of accounting dairy cow depreciation

\begin{tabular}{|l|c|c|c|c|c|c|c|c|c|c|}
\hline & 1 & 2 & 3 & 4 & 5 & 6 & 7 & 8 & 9 & 10 \\
\hline $\begin{array}{l}\text { Carrying } \\
\text { amount }\end{array}$ & 1500 & 1350 & 1200 & 1050 & 900 & 750 & 600 & 450 & 300 & 150 \\
\hline $\begin{array}{l}\text { Size of } \\
\text { accrued } \\
\text { depreciation }\end{array}$ & 150 & 150 & 150 & 150 & 150 & 150 & 150 & 150 & 150 & 150 \\
\hline
\end{tabular}

The size of the accrued accounting amortization is an element of the cost of the yielded production: cow milk and weight gain of calves up to 6 months. The carrying value of the dairy cow is reduced each year with the size of the accrued accounting amortization and approaches 0 at the $8^{\text {th }}$ year of her rearing as a main animal.

On forming the tax financial result the regulated annual amortization norm of $15 \%$ is applied according to law. As a result, the dairy cow is amortised completely in the $7^{\text {th }}$ year of her joining the main herd. (Table 4)

Table 4. Amount of tax depreciation of dairy cow

\begin{tabular}{|l|c|c|c|c|c|c|c|c|c|c|}
\hline & 1 & 2 & 3 & 4 & 5 & 6 & 7 & 8 & 9 & 10 \\
\hline $\begin{array}{l}\text { Unamortised } \\
\text { value }\end{array}$ & 1500 & 1275 & 1050 & 825 & 600 & 375 & 150 & - & - & - \\
\hline $\begin{array}{l}\text { Amount of } \\
\text { accrued } \\
\text { depreciation }\end{array}$ & 225 & 225 & 225 & 225 & 225 & 225 & 150 & - & - & - \\
\hline
\end{tabular}

During the first 6 years after registration of the dairy cow, the tax base is increased by the size of the tax amortization, while after this period, the carrying value of the main animals does not influence the due income tax from the agricultural enterprises.

As a result, a two-fold financial effect is achieved on the producers:

1. The size of the accounting amortization of 150 BG per dairy cow is included in the cost of the products;

2. The tax base at calculation of corporate tax is reduced by the size of the tax amortization reaching 225 BGN per dairy cow, which lowers the value of the due tax.

The application of the tax amortization norms in accounting of a main dairy herd affects negatively the economic results achieved by the agricultural enterprise. The short term of amortization of dairy cows increases the cost of the yielded products which reduces their competitiveness on the milk and calf (up to 6 moths) market. Therefore, at an application of the evaluation at historical cost of dairy cows it is economically reasonable to adopt accounting amortization norms of $10 \%$, in respect to the rearing technology. The application of tax amortization norms of $15 \%$ leads to a reduction of the tax base for income taxation, respectively of the size of the due tax.

\section{CONCLUSION}

The possibilities for amortization of animal carriers are reflected in the achieved economic results by the agricultural enterprises. As a result of the study, the problems of determining the size of the accounting amortization and its taxation interpretation are clearly outlined:

1. Evaluation at fair value, reduced by sales costs, of dairy cows after initial recognition is hindered, due to the influence of both biological, and market factors. The change in the accounting value of main animals is a result of their complex impact which is hard to determine and calculate.

2. Evaluation at historical cost of dairy cows is related to calculating amortization charges for accounting and tax purposes. The application of annual accounting 
GEORGIEVA E., et al.

amortization norms of $10 \%$ reflects the specifics of the technology of raising main dairy herd.

3. The application of the tax amortization norms for accounting purposes has a negative effect on the economic results of the agricultural enterprise, because it increases the cost of the yielded product.

4. The application of annual amortization norms, for accounting purposes of $10 \%$ and for tax $-15 \%$, reflects the technological term of raising dairy cows as productive animals and the regulations of the tax legislation.

The improvement of the accounting for animal carriers could be achieved with the introduction of the following changes in accounting and tax legislation:

1. It is necessary to ascertain the right to a choice on the basis of evaluating animal carriers in the regulation of IAS 14 Agriculture and its Bulgarian equivalent NAS 41 Agriculture: fair value, reduced by sales costs or historical cost, formed by acquisition costs;

2. To regulate accounting amortization norms, relevant to the technological norms of raising separate breeds of animal carriers.

3. To envision a norm in the regulations of the Law of corporate income taxation, with which to adopt for tax purposes such amortization norms, which comply with the technological requirements of raising animal carriers.

\section{REFERENCES}

1. Pancheva, St. "Problems in grouping, recognition and rating of biological assets in agriculture."New Knowledge Journal of Science/Novo Znanie 2.3 (2013)
2. Atanasov,At. "Признаването и оценяването на биологични активи и селскостопанска продукция през призмата на счетоводството“ (2012). Google scholar

3. Bohusova, H., and Svobida, P. "Will the amendments to the IAS 16 and IAS 41 influence the value of biological assets?." Agricultural Economics (Zemědělská Ekonomika) 63.2 (2017): 5364.

4. Gerganov, G. "Счетоводни и данъчни проблеми при оценяване на земеделската продукция." Бизнес управление 1 (2013): 20-37

5. Christensen, Hans B., and Nikolaev, V, "Does fair value accounting for nonfinancial assets pass the market test?." Review of Accounting Studies 18.3 (2013): 734-775.

6. Georgieva, V.,“ Reporting and tax treatment of depreciation of the machinery park in agricultural enterprises". Agraren Universitet Plovdiv-Nauchni Trudove/Scientific works (2014)

7. Lefter, Viorel, and Aureliana Geta Roman. "IAS 41 Agriculture: Fair value accounting."Theoretical and Applied Economics Review 5 (2007): 15-22.

8. Rozentale, Sarmite, and Maira Ore. "Evaluation of biological assets: Problems and solutions."Journal of Modern Accounting and Auditing 9.1 (2013): 57.

9. Международни счетоводни стандарти, Съвет по международни счетоводни стандарти

10.Закон за корпоративно подоходно облагане, ДВ бр.105/22.12.2006, посл. изм. ДВ бр.97/6.12.2016

11.www.mzh.government.bg Система за земеделска счетоводна информация 